\title{
Determining the Ideal Strategy and Modeling in Integrating Spending Reviews in Budget Decision Making at the Ministry of Health of the Republic of Indonesia
}

\author{
Beni Ruslandi ${ }^{1}$, Bahrullah Akbar ${ }^{2}$, Aries Djaenuri ${ }^{3}$, Deti Mulyati ${ }^{4}$ \\ 1,2,3,4 Institut Pemerintahan Dalam Negeri (IPDN), Indonesia \\ Email:b.ruslandi@gmail.com
}

\begin{abstract}
This study aims to find the right strategy and modelling in integrating Spending Review in budget decision making at the Ministry of Health of the Republic of Indonesia. This study uses a qualitative approach with an exploratory method, in which the researcher seeks to explore and build the phenomena being studied to answer the previously formulated problems. The results showed that the spending review integration strategy was divided into three dimensions, namely the organizational size, the process dimension and the time dimension. Meanwhile, the modelling used in integrating spending review in budget decision making in the Indonesian Ministry is known as the Comprehensive Monitoring and Evaluation Model for Budget Management Ministries / Institutions.
\end{abstract}

Keywords: Integration Strategy, Integration Model, Spending Review, Ministry of Health.

\section{A. INTRODUCTION}

Every aspect of budget issues related to social, political, legal, economic, and technically can be considered as particular types of problems (Catalano \& Erbacci, 2018). Because financial issues require economic decisions, social problems require social decisions, political problems require political decisions, and so on (Melkers \& Willoughby, 2018). This argument provides an overview of a comprehensive view of the budget issue, which requires a comprehensive analysis and consideration of many policy alternatives and efficiencies.

It cannot be denied that the nature of economic problems and economic decision-making, combined with the limited time at the formulation phase, requires budget preparers to address non-economic issues in the period before the formulation stage, i.e., in the budget execution phase (Simon, 1959). Of the five types of non-economic decisions, the most dynamic and highly visible are political decisions, which are the main focus of the incremental-political choice model (Thurmaier \& Willoughby, 2001). Budget compilers use the implementation stage to discuss various non-economic problems to identify and compile alternative allocations of resources (Thumaier, 1992).

Then when the budget formulation stage gets to an increasingly intensive stage, budget compilers can concentrate on economic problems. Thus, budget preparers do not need to rely on a streamlined set of decision-making processes to manage the complexities inherent in a comprehensive analysis of budget issues. 
Budget compilers must make full use of the budget cycle to analyze various aspects and combine the analysis from each of these aspects into a budget recommendation to the leadership/government.

Budget compilers carry out various analyzes based on rationality and other things. Budget compilers must discuss the five rationalities inherent in budget issues, especially the political, economic and technical dimensions (Thumaier, 1992). Budget preparers assume that the political dimension reflects the values generated by social decisions and that the economic dimension provides a technically efficient manner. They then formulated recommendations giving weight to the economic and political dimensions. Thus the consideration of technical and economic aspects of various programs is conditioned by the social, political and legal rationality underlying the non-economic aspects of the program. Besides, solving financial and technical problems has a lower priority than political decisions because solving economic and technological issues depends on political decisions.

Economic considerations should be subordinated to political considerations in one of two cases: (a) when political aspects are of primary concern and require redress and (b) when political considerations are not an immediate concern, but budget recipients receive political signals that a technical solution or economics for budget problems can lead to political problems (Thumaier, 1992). The complexity of budgeting can be simplified by filtering various factors into three essential elements, namely political cues and economic factors, to further give weight to these two factors by the budget compiler. The complexity of budgeting can be simplified by filtering various factors into three essential elements, namely political cues and economic factors, to further give weight to these two factors by the budget compiler. The development of budget recommendations can be modelled in the budget decision formula below:

Political variables incorporate ideas about the broader political environment and decision-making structures. The opinions of key actors are essential to budget decisions because they carry the social and political rationality associated with the issue. Economic variables combine notions of the economic environment as well as the financial and technical calculations involved in budget recommendations. Environmental factors include the fiscal climate and options available for external resources. Other factors include technical efficiency and cost-effectiveness analysis that supports various alternatives (Thumaier, 1992).

The budgeting variable (budgeteer) combines policy interpretations, attitudes, and budget values, which in turn are influenced primarily by their level of experience. Budgeteers have considerable influence in the formulation of recommendations because budgeting is more of an art than a science (Thurmaier \& Willoughby, 2001). It is reasonable to expect that more experienced budgeting will produce more effective budget recommendations if supported by more analysis. Strong. Newly recruited budget drafters have a lot to learn, including where to get information on non-economic issues, how to link economic and non-economic aspects and how to read political cues. 
One of the activities carried out to evaluate the budget, and its implementation is spending review activities. Spending reviews are a tool for implementing financial reforms, mainly to increase the availability of fiscal gaps through budget cuts and reallocation.

The results of spending reviews are beneficial in formulating budget policies for the following year because spending reviews are not only related to efficiency and effectiveness but also with decision making and responsibility. However, the results of spending studies in Indonesia have not yet been used for making decisions for the next fiscal year, including budget cuts. This condition makes it difficult for the government to improve the quality of spending (Parhusip, 2016).

There are two reasons for the importance of spending reviews must be part of budget preparation. First, by spending a review, analysis of budget requirements for new programs/activities and budget savings can be carried out simultaneously, so that new programs/activities that have high priority can be determined, and the financing of these programs/activities is carried out without increasing spending because budget savings fund these programs/activities. Second, the level of the depth of spending review can be calibrated in the context of overall budget objectives.

Besides, spending reviews for budget efficiency are increasingly important because there are still various problems in APBN management, namely increasingly limited fiscal space, more enormous mandatory expenditures and expenditures that are not related to improving welfare and public services. These compulsory expenditures include health spending and education spending.

Budget decision making at the Ministry of Health has not taken advantage of the results of the spending review conducted by the Ministry of Finance. This condition is indicated by the fact that there are still seven indicators of the RPJMN Health that have not been achieved and still require hard work even though the realization of health spending continues to increase. Besides, the problems found in the 2017 spending review still occurred and were found in the 2018 spending review, even for einmalig the value increased from Rp180.54 billion in 2017 to Rp.427.20 billion in 2018.

Spending reviews conducted by the Ministry of Finance have not been integrated and become part of the Ministry of Health's budget decision-making process. Therefore, researchers will try to convey the right strategy and modelling to integrate spending reviews in budget decision making at the Ministry of Health. The model of integrating spending review in budget decision making is called "Comprehensive Monitoring and Evaluation Model of Ministry/Agency Budget Management".

\section{B. METHOD}

This study uses a qualitative interpretive approach. Yin defines a qualitative approach as an empirical approach that observes phenomena in the context of reallife, especially when the boundary between a phenomenon and its context cannot be 
clearly defined (Yin, 2014). Compared to several other approaches, a qualitative approach is a structured approach, with well-mapped steps and precise measurement criteria (Dul \& Hak, 2008). The qualitative approach was chosen because this research was conducted through the process of finding, understanding, explaining and obtaining an overview of the phenomena related to the budget decision-making process at the Indonesian Ministry of Health.

The essence of qualitative research is watching people in their environment interact with them, trying to understand their language and their interpretation of the world around them, approaching or interacting with people who are related to the research focus to try to understand, exploring their views and experiences to obtain information or data required (Cassel et al., 2017).

\section{RESULT AND DISCUSSION}

Law Number 36 of 2009 concerning Health states that the goal of health development is to increase awareness, willingness and ability to live healthy for everyone so that the highest degree of public health can be realized, as an investment for the development of socially and economically productive human resources. To achieve these goals, it is necessary to formulate good planning and budgeting. The budget formulation process at the Ministry of Health varies widely, starting from the Formulation of Work Plans (Renja) at the Central level (Ministry/Institutions). Regional Work Plans (provincial and district/city) sourced from the State Revenue and Expenditure Budget (APBN), both from pure rupiah, Non-Tax State Revenue (PNBP) or loans/grants from outside / within the country (P / HL / DN) with various mechanisms. The critical point of the Ministry of Health's budgeting lies in the synchronization between the Central and Regional Governments, especially for the Deconcentration Fund (Dekon), Co-Administration (TP), and the Special Allocation Fund (DAK). Deconcentration is the delegation of part of Government Affairs which is the authority of the Central Government to governors as representatives of the Central Government, to vertical agencies in certain areas, or governors and regents/mayors as the person in charge of general government affairs. Coadministered Tasks are assignments from the Central Government to autonomous regions to carry out part of the Government Affairs which fall under the authority of the Central Government or from the Provincial Government to Regency/City Regions to carry out part of the Government Affairs which fall under the authority of the Provincial Region. Special Allocation Funds (DAK) are funds sourced from APBN revenues, which are allocated to specific regions to help fund special activities which are regional affairs and following national priorities.

Health is one of the national development priorities so that health sector budget planning is an integral part of national development planning which refers to the National Development Planning System (SPPN). By-Law Number 25 of 2004 concerning SPPN, the system is a unitary development planning procedure to produce long-term, medium-term, and annual development plans which are carried 
out by elements of government administrators at the central and regional levels by involving the community.

Based on the Inspectorate General's Review of the Ministry of Health on the 2017, 2018 and 2019 RKA, it is known that there are several notes regarding weaknesses in budgeting at the Ministry of Health. These notes include:

1. Complete data do not yet support the budget proposal;

2. The unit cost rate used in proposing a budget exceeds the determined cost standard;

3. There is an error in user accounts in budgeting for an activity.

This weakness is caused by budget decision making at the Ministry of Health that has not utilized the results of the spending review. Therefore, it is necessary to formulate strategies and models for integration of spend review in making budget decisions at the Ministry of Health.

\section{Integration Strategy}

Based on the analysis of data and information obtained related to the budget decision-making process at the Ministry of Health, in particular, the research activities carried out by the Planning and Budget Bureau of the Secretary-General and RKA reviews conducted by the Inspectorate General of the Ministry of Health, as well as the spending review process carried out by the Ministry of Finance. The strategy for integrating spending reviews in the Ministry of Health's budget decision-making process is as follows:

a. Organizational Dimensions

Improve the quality of planning and budgeting data through improving the quality of research and review at the Main Unit or Echelon I of the Ministry of Health before budget proposal documents are submitted to the Planning and Budget Bureau of the Ministry of Health. Besides, the use of planning and budgeting applications, such as thee-Renggar application, is optimized, among others, through timely inputting of validated data.

Increase the understanding, knowledge and skills of human resources at the Ministry of Health. They are involved in research, review and review of budget documents both human resources in the Main Unit, the Planning and Budget Bureau and the Inspectorate General. Increasing the capacity of human resources can be done through education and training on spending reviews with sources from the Ministry of Finance who have experience in conducting spending reviews. Besides, it could be explored the possibility of conducting internships for Ministry of Health employees at the Ministry of Finance to conduct spending reviews.

b. Process Dimensions

The Ministry of Health coordinates with the Ministry of Finance to overcome obstacles in the form of restrictions in Article 10 paragraph (4) PMK Number 195 / PMK.05 / 2018 concerning Monitoring and Evaluation of Budget Implementation for State Ministries / Institutions which stipulates that the expenditure review report is in the form of a national level spending review submitted to the Director-General of 
Treasury, the Director-General of Budget, and the Minister of Finance. Some solutions that can be done to overcome these obstacles include: 1) proposing amendments to Article 10 paragraph (4) of the PMK by adding Ministries / Institutions as recipients of spending review reports and 2) offering to the Ministry of Finance to conduct focus group discussions with personnel from the Planning and Budget Bureau, the Finance Bureau and the Inspectorate General of the Ministry of Health to discuss the findings and recommendations presented by the Ministry of Finance in the spending review report as well as the follow-up actions that need to be taken by the Ministry of Health in utilizing the spending review report.

Make adjustments to the methodology and scope of the reviews conducted by the Ministry of Health by accommodating the method and area of spending reviews carried out by the Ministry of Finance.

c. The Dimension of Time

The Ministry of Health utilizes the spending review report or information conducted by the Ministry of Finance is conducting a review of the Draft Renja in April each year and conducting a Spending Review on the RKA KL in June / July every year conducted by the Inspectorate General together with the Planning and Budget Bureau of the Ministry of Health.

The proposed integration strategy is supported by the results of a comparative analysis between spending reviews and reviews conducted by the Inspectorate General and the Planning and Budget Bureau of the Ministry of Health. The results of the analysis show that there are several similarities between the activities carried out in spending review activities with the Inspectorate General's review and the Planning and Budget Bureau Research, namely:

Both the APIP spending review and review and the Planning Bureau both conduct a review of the same object, namely RKA K / L Ministries / Agencies. The components of RKA-K / L for each work unit at the level of output, sub-output, subcomponent activities, activities, and programs are the primary input data needed by both APIP spending and review and the Planning Bureau.

Both the APIP spending review and review and the Planning Bureau are aimed at improving the quality of budget execution. The APBN, as one of the government's resources, needs to be used as well as possible to achieve optimal performance while still fulfilling the principles of good governance. All review activities are expected to be able to ensure that every rupiah of APBN money is valuable to improve people's welfare and encourage economic growth. Spending reviews are expected to be able to identify programs/activities that are only once and not repeated in the following fiscal year, determine potential fiscal space, measure government spending from an economic or efficiency and/or effectiveness aspect.

Both APIP spending and review reviews and the Planning Bureau have the potential to be carried out by APIP. The top-down method currently initiated by the Ministry of Finance is one of the initial initiation steps in implementing spending reviews. As the implementation applied to OECD countries, the review approach is bottom-up in which $\mathrm{K}$ / Ls develop their savings options with options that have been 
prepared by the Ministry of Finance. If in the future a bottom-up approach is used, the units that are most suitable for implementing it are APIP and the Planning Bureau at each Ministry / Institution.

Both the APIP spending review and review and the Planning Bureau have the potential to be carried out in the same time cycle. The time frame is not integrated into the budget cycle, which prevents spending reviews from being properly implemented. However, synchronization between these reviews is not impossible to achieve if there is regulatory support that requires that several reviews be carried out in a continuous period.

\section{Integration Model}

The integration of the spending review model into budget decision making at the Ministry of Health can be done by looking at two implementing regulations, namely Regulation of the Minister of Finance Number 195/PMK.05/2018 concerning Monitoring and Evaluation of Implementation and Regulation of the Minister of Health Number 48 of 2017 concerning Planning and Budgeting Guidelines Health. Spending reviews can be seen from two sides, namely as the output of monitoring and evaluation of the budget implementation and as part of a tool of monitoring and evaluation of budget execution.

Monitoring and Evaluation (Monev) at Ministries/Institutions is a series of integrated activities in the framework of reviewing, monitoring and evaluating the implementation of the expenditure budget at the state ministries/institutions. The Minister of Finance is currently carrying out Monev as State General Treasurer (BUN) and each Ministry/Institution as Budget User (PA). However, the evaluation in the form of a spending review has not been carried out by the Ministry of Health so that it is not yet part of the Ministry of Health's planning and budgeting cycle.

A study conducted by the World Bank on the implementation of spending reviews in several countries shows that spending reviews are likely to be most effective if they are closely integrated into the budgeting process of Ministries/Agencies. To increase the effectiveness of spending reviews in Indonesia, it is essential if the spending review is carried out by the Ministry of Health and integrated into the Ministry of Health's budget decision-making process. The integrated spending review model in the Ministry of Health's budget decision making is called the "Comprehensive Monitoring and Evaluation Model of Ministry / Agency Budget Management".

Based on this model, it is known that there is a link between the budget cycle, monitoring and evaluation of the budget implementation and spending review. Spending reviews are an integral part of the budget cycle, namely as part of the monitoring and evaluation phase. Monitoring and evaluation can be divided into two major parts, namely monitoring and assessment throughout the year and spending reviews which are carried out once in an annual budget cycle to provide input for planning and budgeting for the next period. 
Implementation of a Comprehensive Monitoring and Evaluation Model in Budget Management of Ministries / Institutions in this case at the Ministry of Health is described in the following activities.

1. In March, the Ministry of Health invited the Ministry of Finance officials to submit and discuss the results of the spending review at the Ministry of Health. The material presented included findings and recommendations which must be followed up by the Ministry of Health. The delivery and discussion were carried out in a technical meeting on indicative ceilings which was held after the Ministry of Health obtained a Joint Letter regarding the Draft Indicative Ceiling. The purpose of conveying and discussing the results of the spending review in this activity is so that the recommendations submitted by the Ministry of Finance in the Spending Review Report can be followed up by all Main Units of the Ministry of Health in drafting the $t+1$ year Renja. With the Ministry of Finance's recommendations being discontinued, it is hoped that the Renja will no longer budget for the activities at issue in the spending review report.

2. At the latest in early April, the Planning and Budget Bureau of the Ministry of Health will conduct a review of the draft Renja-K / L Main Unit / Satker. The review of the draft Renja-K / L involved the Inspectorate General. One of the aspects studied is ensuring that the Main Unit / Satker has followed up on the Ministry of Finance's recommendations in the spending review report.

3. After the Ministry of Health compiles the RKA K / L based on the Draft Budget Ceiling Plan that has been approved by the President, between the end of June-early July the spending review of the RKA-K / L budget ceiling by a team from the Planning and Budget Bureau and the Inspectorate General. Spending reviews in this stage are carried out to determine activities/outputs/components, and the budget that will be reduced due to a reduction in the value of the budget ceiling compared to the indicative ceiling used when compiling the Renja. By carrying out a spending review at this stage, the reduction of activities/ outputs/ components and the budget has a clear basis. Through this spending review activity, the Ministry of Health will determine the priority order of activities/outputs/components. It's budget based on specific criteria, for example, the suitability of activities with government priorities, activities that provide the most significant economic value, activities most needed by the community and activities that cannot be funded by parties. Private or local government.

\section{CONCLUSION}

The strategy for integrating spending review in budget decision making is: a) improving the quality of planning and budgeting data through improving the quality of research and review at the Main Unit or Echelon I of the Ministry of Health before budget proposal documents are submitted to the Planning and Budget Bureau of the Ministry of Health; b) increase understanding, knowledge and skills of 
human resources at the Ministry of Health who are involved in research, review and review of budget documents and spending reviews; c) Coordinate with the Ministry of Finance to overcome obstacles in the form of restrictions on the distribution of spending review reports in Article 10 paragraph (4) PMK Number 195 / PMK.05 / 2018; d.) Making adjustments to the methodology and scope of the reviews conducted by the Ministry of Health by accommodating the method and area of spending reviews carried out by the Ministry of Finance. e) Utilizing spending review reports or information conducted by the Ministry of Finance is conducting a review of the Draft Renja and conducting a Spending Review on the RKA KL.

The model of integrating spending review in budget decision making is called "Comprehensive Monitoring and Evaluation Model of Ministry / Agency Budget Management". With this model, spending review becomes an integral part of the budget decision-making cycle, especially as part of monitoring and evaluation activities that were not previously carried out by the Ministry of Health.

\section{REFERENCES}

1. Andrews, M., \& Hill, H. (2003). The impact of traditional budgeting systems on the effectiveness of performance-based budgeting: a different viewpoint on recent findings. International Journal of Public Administration, 26(2), 135-155

2. Arena, M., \& Arnaboldi, M. (2013). Debate: Dealing with spending reviewsItaly. Public Money E Management, 33(1), 4-6.

3. Berry, C. and D. Sinclair (2010). Intergenerational Fairness and the Spending Review 2010. London UK: Intergenerational Longevity Centre.

4. Brugnon, G. P. N. (2013). Public Engagement Practices in Spending Review Processes of the UK, Italy and France. Master Graduation Thesis, Politecnico di Milano, Italy.

5. Cassell, C., Cunliffe, A. L., \& Grandy, G. (Eds.). (2017). The SAGE Handbook of Qualitative Business and Management Research Methods. London: Sage.

6. Cassell, C., Cunliffe, A. L., \& Grandy, G. (2017). The SAGE Handbook of Qualitative Business and Management Research Methods. London: Sage.

7. Catalano, G., \& Erbacci, A. (2018). A theoretical framework for spending review policies at a time of widespread recession. OECD Journal on Budgeting, 17(2), 924.

8. Creswell, J. W. (2014). Research design: qualitative, quantitative, and mixed methods approaches-4th ed. SAGE Publications, Inc

9. Diamond, P. (2013). 'Spending Wisely: Principles for a Good Spending Review': The First Report of the Fabian Commission on Future Spending Choices. The Political Quarterly, 84(4), 527-533

10. Direktorat Jenderal Perbendaharaan, Kementerian Keuangan RI. (2018). Spending Review 2018: Meningkatkan 'Value for Money' Belanja Kementerian / Lembaga; Kementerian Keuangan.

11. Direktorat Penyusunan APBN, Direktorat Jenderal Anggaran, Kementerian Keuangan RI. (2017). Informasi APBN 2017; APBN yang Lebih Kredibel dan Berkualitas di Tengah Ketidakpastian Global. 
12. Ferry, L., \& Eckersley, P. (2015). Budgeting and governing for deficit reduction in the UK public sector: act three accountability and audit arrangements. Public Money \& Management, 35(3), 203-210.

13. Fischer, F. (2003). Reframing Public Policy: Discursive Politics and Deliberative Practices. NewYork: Oxford University Press.

14. Hawkesworth, I. and K. Klepsvik. (2013). Budgeting levers, strategic agility and the use of performance budgeting in 2011/12. OECD Journal on Budgeting.

15. Irvin, R. A., \& Stansbury, J. (2004). Citizen participation in decision making: is it worth the effort? Public Administration Review, 64(1), 55-65.

16. Melkers, J. E., \& Willoughby, K. G. (2001). Budgeters' views of state performance-budgeting systems: Distinctions across branches. Public Administration Review, 61(1), 54-64.

17. OECD. (2011). Typology and Implementation of Spending Reviews. OECD SBO Meeting on Performance and Results, November 2011.

18. Parhusip, B. (2016). Analisis Implementasi Spending Review pada Kementerian Negara/Lembaga Tahun 2013-2015. Kajian Ekonomi dan Keuangan, 20(3), 191-211.

19. Pollitt, C., \& Bouckaert, G. (2017). Public management reform: A comparative analysis - Into the age of austerity. New York: Oxford University Press.

20. Postuła, M. (2017). Spending Reviews-a Tool to Support the Efficient Management of Public Funds. Journal of Management and Business Administration, 25(2), 63-90.

21. Prabowo, C. E. (2018). Spending review 2018: Meningkatkan value for money belanja pemerintah. Indonesian Treasury Update, 3(2), 30-42.

22. Robinson, M. (2013). Spending Review. Working Party of Senior Budget Officials. 3'th Annual Meeting of OECD Senior Budget Officials, OECD Conference Centre, Paris, 3-4 June, 1-8.

23. Robinson, S. E. (2003). Bureaucrats and public schools: Does bureaucratization promote incrementalism in program budgeting for Texas school? The University of Texas at Dallas Political Economy Working Paper, Richardson, Texas.

24. Rutgers, M. R., \& Van Der Meer, H. (2010). The origins and restriction of efficiency in public administration: Regaining efficiency as the core value of public administration. Administration $\mathcal{E}$ Society, 42(7), 755-779.

25. Simon, H. A. (1959). Theories of decision-making in economics and behavioural science. The American Economic Review, 49(3), 253-283.

26. Thurmaier, K. (1992). Budgetary decision-making in central budget bureaus: An experiment. Journal of Public Administration Research and Theory, 2(4), 463-487.

27. Thurmaier, K. (1995a). Execution Phase Budgeting in Local Governments: It's not just for control anymore! State $\mathcal{E}$ Local Government Review, 27(2), 102-117.

28. Thurmaier, K. M., \& Willoughby, K. G. (2001). Policy and politics in state budgeting. New York: M. E. Sharpe.

29. Van Dooren, W., Bouckaert, G., \& Halligan, J. (2015). Performance Management in the Public Sector. New York: Routledge. 
30. World Bank. (2013). Beyond the annual budget: global experience with medium-term expenditure frameworks. Washington, DC: World Bank.

31. Yin, R. K. (2014). Case Study Research Design and Methods: Applied Social Research Methods Series. Thousand Oaks 